\title{
The Genus OCHnA.
}

\author{
By E. P. Philtipe, M.A., D.Sc., F.L.S.
}

The National Herbarium has on many occasions received specimens of Ochna from the Forest Department for identification, but found that the naming of the specie, in herbaria was unsatisfactory. Forest officers have suggested that more species are found in the South African forests than those generally accepted as occurring within the Union, and as some of the species are of economic value it was pointed out by the Chief Conservator of Forests that the genus should be critically examined. With the permission of the Chief of the Division of Botany the writer undertook this work. Without the cordial co-operation of the Forest Department this would not have been possible, and my appreciation is here expressed of the willing assistance received from Mr. J. J. Kotze, B.A., B.Sc., the acting Research Officer at the time. To the various forest officers who have supplied specimens and information the writer is also deeply indebted, especially to Mr. A. J. O'Connor, the District Forest Officer at Doornboom, northern Transvaal, who first pointed out the existence of two distinct species of Ochna which occur in the Woodbush Forest, and which had previously been regarded as either O. arborea or O. atropurpurea, var. natalitia. My thanks are also due to the Director of the South African Museum, who allowed me facilities for working at the Cape Governmert Herbarium, and to Dr. S. Schönland, Mrs. F. Bolus, B.A., Mrs. R. Potts, and Dr. P. J. van der Bijl for lending me the material in their respective herbaria, and to the Director of Kew for comparing some specimens with the Kew material.

At first sight the division of the genus into species appeared an easy matter, but as more material was examined the difficulties of limiting the species increased. The writer has critically examined nearly 200 herbarium sheets, but fajled to find any constant characters, either floral or vegetative, which could be used as diagnostic characters for a key to the species, and has had to rely on the general "facies" of the specimens in most cases and has found it difficult to express the differences in words. That the specimens have been grouped correctly may be assumed, as handling a large number of specimens makes one familiar with their "look," but whether a particular specimen can ke readily placed in its correct species with the aid of the key given hete is more doubtful. However, this difficulty will only apply to a few species related to 0 . atropurpurea; the others are fairly distinct.

In the "Flora Capensis" (Vol. I, 448), three species of Ochna are described, but my investigations show that there are nine distinct species in South Africa with the possibility of a tenth. This latter is represented by two sheets illustrating a plant with a prostrate habit, but as Harvey, in the "Flora Carensis" under O. arborea, mentions that " shoots from the roots occasionally produce flowers," it is just possible that the specimens may represent such shoots, but no information on this point is available. In all the herbarium specimens examined only $O$. pulchra was correctly distinguished, while the limits of $O$. arborea and $O$. atropurpurea were confused. O. pulchra is a typical Transvaal species, but also occurs in Rhodesia. and as far as our records go is absent from the Cape Province and Natal. It is readily distinguished from all the other South African species by the large racemose inflorescence. Other distinguishing characters are the entire leaves (or they usually appear entire to the naked eye) and the long stigmas, which are one-third to a quarter the length of the style. The other species which has entire (or apparently so) leaves is O. arborea, but this does not occur in the Transvaal. It has been recorded from the George, 
Kynsna, Uitenhage, Albany, Stockenstrom, East London, Kingwilliamstown, Komgha, and Kentani Divisions, and then appears in Natal and extends to Lourenco Marques The inflorescence in this species is also racemose (a very abbreviated raceme), but specimens have passed through $\mathrm{my}$ hands in which the flowers are either solitary or 2-4-nate at the apex of short shoots; this is, however, very rare. The third species, $O$. atropurpurea, as I have limited it, is composed of plants of a shrubby habit, $2-3 \mathrm{ft}$. high, and can usually be recognised at a glance by the branches having a distinct lepidote appearance due to the presence of numerous prominent lenticels; the leaves are usually elliptic, sharply serrated, and the flowers solitary. It has a similar distribution to 0 . arborea, but has also been recorded from Zululand and Barberton. The variety natalitia has been kept as a distinct species; it differs from $O$. atropurpurea in habit, and the branches have not the lepidote appearance; the flowers are rarely solitary, and the leaves longer and lancenlate. Though Harvey recognized this variety, he has nevertheless confused it with the species, as in the Cape Government Herbarium there is a sheet (E. and Z. 925) labelled on the ticket $O$. atropurpurea and written up as such in Harvev's handwriting, which is undoubtedly $O$. natalitia. This species is not so common in the south-eastern districts as $O$. atro purpurea, but is recorded from several localities in Natal, and then passes through Swaziland to Barberton. Ecklon and Zeyher record it from the Uitenhage Division. The correct limitation of this species has proved the most troublesome, and at first I was inclined to recognize three species. A further examination proved that the first grouping of the specimens was very artificial and that this species should be regarded as a variable one with a wide range of distribution. O. Chilcersii appears to be confined to the eastern forests, it resembles O. natalitia in general habit, but is readily distinguished from this species by the larger number of carpels in the ovary, and the flowers are usually much larger. The two species, O. O'Connorii and O. Holstii, which accur in the Woodbush Forest are very distinct from all the other South African species. Both are deciduous trees of timber size, and may perhaps be confused in herbaria if leaves are only present, but they differ considerably. $O$. Holstii has a rough bark and ellipsoid fruits, while O. O'Connorii has a smooth bark with kidney-shaped fruits. The remaining species, O. leptoclada, is found in the Barberton and Lydenberg Districts and also in Rhodesia. Specimens in mature foliage are easily recognized by the oblanceolate leaves, which are long attenuated at the base.

The African species of Ochna were monographed by Diels in 1904 (Engl., "Bot. Jahrb.," Vol. XXXIII, p. 232), to which account the reader is referred for a key to all the known African species.

The writer was granted facilities by Mr. Kotze for extracting information about the species from notes sent to the Forest Department by various forest officers.

O. Chilversii. This species is known in the Cwebe Forest by the natives as "sibomvu." The Conservator of Forests, Transkeian Conservancy, remarks: "I was struck with the nice appearance of the wood. It is a soft (hardwood), easy to work. . . . It is plentiful in the Cwebe and other coast forests and approximates arborea in size, and could easily be exploited. Possibly it might make an excellent hammer handle." Mr C. C. Robertson remarks on the difference between this species and $O$. arborea. He reported that the "wood, which seems to me far from soft, appears to have the same general character as boxwood, and would probably be suitable for similar purposes," and he suggested that it might be tried for whatever purpose O. arborea is used for. The forester at Cwebe, who has handled the wood, describes it as " easy to work and soft."

In the Notinsela Forest the natives know the tree as " umbomvane umncince," and according to Mr. F. M. Fegen the tree occurs both in the Notinsela and Mpimbo Reserves, and appears to be plentiful in the latter locality, and no doubt also in the surrounding forests.

Forester Chilvers mentions that he has only seen one specimen in the Ingeli Forest Reserve. He describes it as a "small tree, stem 5 inches in diameter; bark not smooth as in $O$. arborea ; leaves not diciduous." 
O. Holstii. This species occurs in the Ingeli Forest Reserve and is also found in the Woodbush Forest in the northern Transvaal. The specimens in the Ingeli Reserve, Forester Chilvers describes as "trees of timber size with deciduous leaves; stem attaining to a diameter of $2 \mathrm{ft}$. to $2 \mathrm{ft} .6 \mathrm{in}$. with a rough bark." The species is quite plentiful at Ingeli and is known to the sawyers as the "leal red pear" as distinguished from Scolopia. Forester Tustin describes this species as " a branched tree $40-50 \mathrm{ft}$. high, stem 18 in. in diameter, with a bole 15-20 ft. Bark grey on the outside and deep red inside. Flowers in September and October and fruits ripen in December. I have only found the tree growing in denser parts of the forest. It is found throughout my patrols (Impetyne and Ingeli) and is sparingly dotted through the forests. Saplings are numerous compared with old trees. I have not seen this tree used for any purpose.:'

District Forest Officer A. O'Connor, in submitting specimens from the Woodbush Forest, states it to be "a fairly large deciduous tree. The bark is comparatively smooth, though not with the hard smoothness of $O$. O'Connorii, being more flaky and ' chippy.'" It is beet-red under the surface.

Mr. O. Miller (the acting District Forest Officer at Doornboom at the time) states that the species is fairly abundant in the lower, but scarce in the upper, slopes of the Woodbush Forest. It attains a height of $45 \mathrm{ft}$, with a trunk diameter, at breast high, of 30 in. The species flowers in November and sets its fruits in January.

O. O'Connorii. This tree has only been recorded from the Woodbush Forest, and was collected by Mr. A. J. O'Connor. He noted the differences between this and O. arborea, and describes it as a " small tree with smooth bark, very much like the ordinary Cape plane." The local name is " rooihout," "rooi izerhout."

0 . arborea. This species may attain the size of a timber tree or may be only 8-10 ft. high. In the Horseshoe Forest, Kingwilliamstown, Forester Whithal records this species as a "tree $30 \mathrm{ft}$. high, with a diameter of $26 \mathrm{in}$. at breast high, and is found on a dolerite formation." At Knysna, Mr. J. D. Keet, the District Forest Officer, records it " as common in all parts of the district, being a small tree which forms part of the under storey of the forest. and rarely reaches a height of $1 \mathrm{ft}$. at breast high." Locally known as the " rooihout." The wood is very strong and of great durability, and is generally used for making: handles of tools and axes. The seeds are said to be attacked by caterpillars. Forester Watton states it to be a plant growing in scrub at $\mathrm{Kn}$ sna, and is known by the name of "rooihout." Forester Strauch sends the following notes with his specimens:" Very plentiful in all the reserves in this (Alexandria) forestal district, and is found throughout the forest. Average height, $10 \mathrm{ft}$. ; average girth, $4 \mathrm{in}$. In the kloofs it grows much larger and it is found that the bark is much lighter than in trees growing on ridges or exposed positions. The timber is used for making axe and hammer handles. The tree appears to grow more or less plentifully over the forests in the Alexandria District, which are all on sandy soil."

Sim* is in error when he states that this species occurs in the Transvaal.

$O$. natalitia. This species, which has been regarded as a variety of $O$. atropurpurea, rightly deserves specific rank. Forester F. M. Fegen reports it as a "small tree about $6 \mathrm{ft}$. high growing at Notinsela Forest. It is very free in flowering and has scented flowers. I have seen several specimens of this tree in the Mpimbo Forest, but it does not appear to grow higher than 6 or $8 \mathrm{ft}$. Many young plants of $O$. atropurpurea are growing close to this." Forester Fegen further remarks that both species $(O$. natalitia and $O$. atropurpurea) grow on the edge of the forest and appear to be gregarious, growing thickly together. I have not found them well in the forest. Many stunted plants are in "dobo" grass, and have been scorched by fire and have thrown out branches from the base. This species should make a handsome garden plant, and fruiting specimens are particularly beautiful. The Pondos call it " mbomvane ncinci," but do not appear to use it for any purpose. 
O. atropurpurea. Forester Fegen records this as a "small shrub growing to edge of Maseko Forest and which is very plentiful. It has flowered and fruited very sparingly this year (1915) and fruiting specimens are scarce. The leaves, although identical in shape, are smaller on every specimen than those of $O$. natalitia. It is also found at Notinsela. Galls are nearly always present, and the plants, like $O$. natalitia, are confined to the edge of the forest." *

O. pulchra. A small or large tree, 6-20 ft. high. The trunk is smooth and usually white, which makes the recognition of this tree in the veld easy. It is usually in flower late in September, and at the end of October the sepals take on a red colour which makes the species so conspicuous. The young fruits are then forming, and they mature in December. The flowers are sweetly scented; at first the sepals are bright green, then change to olivebrown and red. The seeds are said to be poisonous.

\section{KEY TO SPECIES.}

Inflorescence in definite long or short racemes, sometimes panicled, very rarely solitary or 2-3-nate at the apices of short shoots, but if so then the leaves entire or appearing entire to the naked eye.

Ovary of $10-13$ carpel.

Ovary of less than 10 carpels.

Leaves entire or appearing entire to the naked eye (rarely serrated, but if so, then never with prominent lenticels), not acuminate; bark smooth.

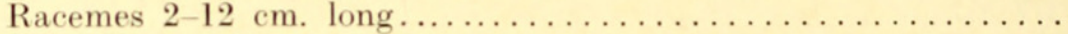

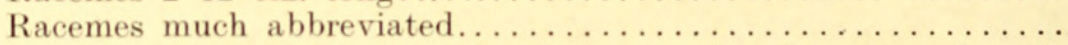

Leaves serrated, long acuminate, branches not densely covered with prominent white lenticels; fruit ellipsoid..................

Leaves serrated, shortly acuminate or cuneate at the apex, rarely rounded; branches sometimes covered with prominent white lenticels; fruits ellipsoid or kidney-shaped.

Fruits kidney-shaped; lenticels not numerous and prominent; a tall tree.

Leaves obtuse; Transvaal species...............

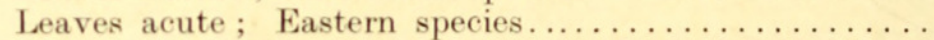

Fruits ellipsoid, lenticels numerous and prominent; a large

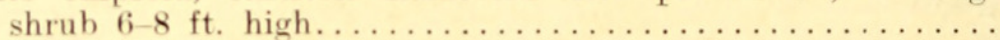

Chilversii.

pulchra.

arborea.

Holstii.

O'Connorii.

arborea.

natalitia.

Inforescence solitary or 2-4-nate arising from tha apex of abbreviated shoots.

Small trees or erect shrubs.

Mature leaves up to $9 \mathrm{~cm}$. long, oblanceolate, usually long-attenuate at

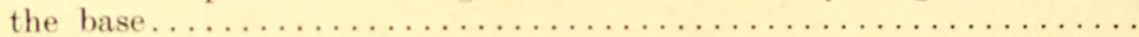

Mature leaves very rarely up to $8 \mathrm{~cm}$. long, rounded or narrowed at the base, never long-attenuate.

Flowers 2-5-nate on much abbreviated shoots from the axils

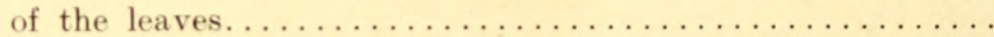

Flowers solitary, very rarely $2-5$-nate, but then arising from the apex of short shoots and not in the axils of the leaves.

Lenticels usually dense and prominent, giving the branches a lepidote appearance to the naked eye; teeth on the margins of the leaves usually triangular

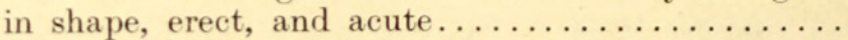

Lenticels usually present, but branches not appearing lepidote to the naked eye; teeth on margins of leaves usually incurved.

Epidermis flaking from the branches in membranous strips; leaves up to $4 \mathrm{~cm}$. long..

Epidermis rarely evidently flaking in membranous strips; leaves up to $8 \mathrm{~cm}$. long.. natalitia.

0. Chilversii Phillips. Arbor parıa. Cortex sulcata. Folia, 3-8 cm. longa, 6-2.5 cm. lata, lanceolata, apice obtusa, basi cuneata, glabra, marginibus serratis. Inflorescentia in racemo brevissime disposita. Ovarium, 10-13 carpellis. 
A small tree with a trunk 5 in. in diameter. Bark rough. Branchlets with reddish-brown to almost black bark, pustulate or not, not flaking. Leaves $3-8 \mathrm{~cm}$. long, $6-2.5 \mathrm{~cm}$. broad, lanceolate, rarely more or less oblanceolate, obtuse, cuneate at the base and passing into a short petiole, rarely rounded, with the midrib distinct above and beneath and the lateral veins evident or not, with serrated margins, glabrous. Inflorescence on short shoots in abbreviated racemes, up to 7 -flowered. Pedicels $1 \cdot 7-2 \cdot 2 \mathrm{~cm}$. long, terete, articulated 1-3 mm. from the base, glabrous. Sepals $1.4 \mathrm{~cm}$. long, $\cdot 7 \mathrm{~cm}$. broad, ovate, obtuse, and rounded at the apex ; two of the sepals cucullate at the apex, glabrous (in dried specimens the folding of the sepals gives them the appearance of being acuminate). Petals $1.7 \mathrm{~cm}$. long, $1.4 \mathrm{~cm}$. broad, obovate, rounded at the apex, narrowed at the base into a short broad claw. Filaments $5.5 \mathrm{~mm}$. long; anthers $3 \mathrm{~mm}$. long, linear-oblong in outline, dehiscing by two apical slits. Ovary of 10-13 carpels, about $1 \mathrm{~mm}$. long; style $1 \mathrm{~cm}$. long, somewhat compressed; stigmas either capitate or saucer-shaped, with the stigmatic surfaces arranged round the rim. Fruit unknown.

Eastern Region.-Cwebe Forest, July, Pretorius in Herb. Forest Dept. 1625 ; Notinsela Forest, Fegen in Herb. Forest Dept. 1817; Ingeli Forest Reserve, December, Chilvers in Herb. Forest Dept. 1945 ; at mouth of Umkwani River, October, Tyson, 2619.

O. pulchra (Hook. fil., Ic. Pl. t. 588).

A small or large tree, 6-20 ft. high. Branches usually white or light grey to brown in colour, quite smooth or rough, with the epidermis peeling off in membranous flakes. Leaves subsessile, $3 \cdot 5-11 \mathrm{~cm}$. long, 1·5-5 cm. broad, usually elliptic, sometimes elliptic-lanceolate, rarely oblanceolate, rounded or obtuse at the apex, sometimes mucronate, usually narrowed at the base, more rarely rounded or subcordate; margins entire or appearing entire to the naked eye, more rarely with subulate teeth adpressed to the margins, with the mid-rib prominent beneath and the lateral veins distinct, glabrous. Inflorescence a many-flowered raceme, 2-12 cm. long. Pedicels $1-2.5 \mathrm{~cm}$. long, glabrous, articulated at the base. Sepals 6-8 mm. long, $5 \mathrm{~mm}$. broad, elliptic or suborbicular, obtuse, sometimes with cartilaginous teeth on the margins. Petals $7 \cdot 5-9 \mathrm{~mm}$. long, $4 \cdot 5-5.5 \mathrm{~mm}$. broad, obovate, narrowed at the base. Filaments $2 \mathrm{~mm}$. long; anthers $1 \cdot 5-2 \mathrm{~mm}$. long, oblong or oblong-linear in outline. Ovary of 5-7 carpels; style $2 \mathrm{~mm}$. long; stigmas as many as the carpels, about one-third to a quarter as long as the style, recurved, with faintly bilobed apices. Fruit $1 \cdot 1-1 \cdot 3 \mathrm{~cm}$. long, $8 \mathrm{~mm}$. in diameter, kidney-shaped, and attached to the torus at the middle.--" Flora Capensis," I, 449.

Transvaal. - Northern Transvaal without precise locality, Becker in Herb. Albany Mus.; Pretoria District: Premier Mine, Rogers 19846; Magaliesberg, October, Burke 302, Schlechter 3623; Meintjes Kop, September, Robertson in Herb. Forest Dept. 1662 ; kopjes round Pretoria, September, Miss Leendertz 300, 381, May, Burtt-Davy 2449 ; Koedoespoort, September, Miss Stent in Govt Herb. 10527 ; Wonderboom, October, G.A.Z. in Herb. Forest Dept. 1686, Mogg in Herb. Forest Dept. 1673 and in Govt. Herb. 11509, Galpin 6977, Burtt-Davy 2678 and in Herb. Forest Dept. 545, Miss Leendertz 431. Rustenburg Dist. : Plains at font of Magaliesberg, Miss Pegler 1032 ; Wolhuterskop, Howlett in Govt. Herb. 16176, Pole Evans in Govt. Herb. 15843; Silikats Nek, De Kroon, Putterill in Govt. Herb. 16176; Rustenburg, Miss Leenderts 3369. Waterberg Dist.: Warmbaths, BurttDavy 2626 ; Leeuwpoort Tin Mines, Rogers 19071, 21874; Pietpotgietersrust, Burtt Davy 2289, Miss Leendertz 5635, 2392, Collector (?) in Herb. Bolus 10a; Chunies Poort, Pole Evans 19460.

Rhodesia.--Veld; Victoria Falls, August-October, Miss Gibbs 305 ; sandy soil, Victoria Falls, 3000 ft., Rogers, 5301, 5302, 5423 ; in open forest, Victoria Falls, 2900 ft., Galpin 7050 ; Livingstone, $3000 \mathrm{ft}$., October, Rogers, 7450 ; Victoria, Monro 1594, 2108.

This species is usually in flower late in September, and at the end of October the sepals take on a red colour which makes the plant so conspicuous. The young fruits are then forming and they mature in December. The flowers are sweetly scented; at first the sepals are bright green, then change to olive-brown and red. The seeds are said to be poisonous. 
0. arborea (Burch. ex D.C. Prodr. 1, 736).

A shrub $8 \mathrm{ft}$. to a tree 30-49 ft. high. Bark smooth. Branches with light or dark grey bark, with prominent lenticels and with the epidermis often peeling in membranous flakes. Leaves subsessile, $1 \cdot 5-6.5 \mathrm{~cm}$. long, $0 \cdot 8-3 \mathrm{~cm}$. broad, mostly elliptic more rarely lanceolate-elliptic or obovate, obtuse or rounded at the apex, rarely acute, narrowed or rounded at the base, quite entire or appearing so to the naked eye, very rarely distinctly serrated; teeth when present more or less subulate and adpressed to the margin of the leaf (except $W$ ood 5878 , in which the serrations are distinct). Inflorescence less than $1 \mathrm{~cm}$. long, in a much abbreviated raceme of 3-7 flowers, very rarely solitary or 2-3-nate at the apex of short shoots. Pedicels $0 \cdot 7-1 \cdot 2 \mathrm{~cm}$. long, articulated about $1 \mathrm{~mm}$. from the base. Sepals $6.5 \mathrm{~mm}$. long, $3.5-5 \mathrm{~mm}$. broad, elliptic or ovate-elliptic, rounded at the apex. Petals $\cdot 75-1 \cdot 3 \mathrm{~cm}$. long, $3-5.5 \mathrm{~mm}$. broad, oblong or oblong-obovate, cuneate at the base. Filaments $2.5-3 \mathrm{~mm}$. long; anthers $1.5 \mathrm{~mm}$. long, oblong in outline. Ovary of $4-6$ carpels ; style 5.5-6 mm. long; stigmas as many as the carpels, or sometimes stigma subglobose. Fruit ellipsoid or almost kidney-shaped, attached to the torus at the middle.-." Flora Capensis," I. 449; Sim, "Forest and Forest Flora," 163 pl. xxix.

George Dist.: George, August, Rogers 4039; Woodville Forest, George, Sim in Herb. Forest Dept.3116,3117. Knysna Dist.: Knysna Commonage, Keet 498; Christies Kloof, Gouna, near Knysna, Collector (?) in Herb. Forest Dept. 1342 ; Gouna River, September, Keet in Herb. Forest Dept. 2529 ; Kaffirkop Forest, c. $1500 \mathrm{ft}$., January, Watton in Herb. Forest Dept. 2943; De Eiland, Rabbets in National Herb. 1420, 1421. Uitenhage Dist.: Oliphants Hoek and Addo, September-October, E. and Z. 924; Zuurberg, Drège. Alexandria Dist.: Forests near Alexandria, Strauch in Herb. Forest Dent. 3012, 3013, 3005. Albany Dist.: Blaauw Krantz Bridge, Octoher, Galpin 265: without precise locality, E. and Z.; Bothas Hill, December, Salisbury 357 ; Salentown, Zeyher; near Crahamstown, MacOwan 110. Stockenstrom Dist.: Katberg Mrs. Hobson 1446. East London Dist. : Coast near East London, April, Sim 2153; East London, July, Miss Gane 260; near Nahoon River, August, Galpin 3291. Kingwilliamstown Dist. : Along the Buffalo River, near Kingwilliamstown, November, Flanagan 359 ; Horseshoe Forest, December, Whithal in Herb. Forest Dept. 2941 ; Mkobisa Forest, December, Van der Merwe in Herb. Forest Dept. 2939 ; Western Pirie Forest, January, Kopke in Herb. Forest Dept. 2940. Victoria East Dist.: Auckland Forest, January, Ackermann in Herb. Forest Dept. 2942. Komgha Dist.: Woods near Prospect Farm, November, Flanagan 359. Kentani Dist. : Forest near Kentani, July, Miss Pegler 1216. Pondoland, Mpingo Forest, Fegen in Herb. Forest Dept. 3033, 3089.

Natal: Port Natal, Gueinzius; Inanda, August, Wood 687, and in Natal Govt. Herb. 5878 ; without precise locality, Gerrard and McKen 834, and in Natal Govt. Herb. 73 ; Victoria County, Wood: Shafton, Howick, Mrs. Hutton 153.

Delagoa Bay: E. and Z. 926 ; Madame Borl’́ 176, 16 ; Rogers 21373.

A large shrub $(\boldsymbol{W o o d})$. A forest tree, $15 \mathrm{ft}$. high, with masses of yellow flowers (Miss Pegler). A small tree throughout the whole of the Knysna Forest; generally used for making handles of tools and axes; wood very strong and heavy and of great durability; seeds attacked by caterpillars (Herb. Forest Dept. 1342).

O. O'Connorii, Phillips. Arbor. Cortex plana. Folia $5-10 \mathrm{~cm}$. longa, $1 \cdot 3-5 \mathrm{~cm}$. lata, lanceolata, raro elliptica vel ovato-lanceolata, apice paullo angustata, obtusa, Inflorescentia in racemo brevissime disposita; flores solitarii vel 2-3-nati. Fructus $1.5 \mathrm{~cm}$. long, $8 \mathrm{~cm}$. latus, reniformis.

A tree. Bark comparatively smooth, somewhat flaky and " chippy," beet-red beneath the surface $\left(O^{\prime}\right.$ Connor). Branchlets somewhat pustulate, reddish-brown to dark-brown in colour, not flaking. Leares $5-10 \mathrm{~cm}$. long (usually $6-8 \mathrm{~cm}$. long), 1-3.5 cm. broad, lanceolate, rarely elliptic or ovate-lanceolate, slightly tapering at the apex, rarely acuminate or rounded and retuse, obtuse, sometimes slightly tapering to the base and rounded, with the mid-rib 
prominent above and beneath and the lateral veins distinct above; glabrous. Infloresence racemose with the flowers either solitary or 2-3-nate in the raceme. Pedicels $1-2 \cdot 2 \mathrm{~cm}$. long, articulated 1-4 mm. from the base. Sepals $7 \mathrm{~mm}$. long, $5 \mathrm{~mm}$. broad, broadly elliptic, rounded at the apex. Petals $1 \cdot 1-1 \cdot 2 \mathrm{~cm}$. long, $5-6 \cdot 5 \mathrm{~mm}$. broad, obovate, rounded above, narrowed into a short broad claw at the base. Filaments $2.5 \mathrm{~mm}$. long, anthers $2.5 \mathrm{~mm}$. long, linear-oblong in outline. Ovary of 5-6 carpels ; style $5.5 \mathrm{~mm}$. long ; stigmas as many as the carpels. Fruit $1.5 \mathrm{~cm}$. long, $0.8 \mathrm{~cm}$. broad, kidney-shaped, attached to the torus at the concave side.

Transvaal.--Barberton Dist.: Van der Merwes Bush, Pilgrims Rest, 5-5750 ft., January, Burtt-Davy 1409; Barberton, February, Orangie in Colonial Herb. 1691 ; Legat in Colonial Herb. 1316. Pietersburg Dist.: Woodbush Forest, October, Grenfell 3, and in Colonial Herb. 1017 ; Dwyer; December-January, Botha in Herb. Forest Devt. 2929, 2934; Legat in Herb. Transvaal Mus. 9711; by stream at Potatobush, c. $4750 \mathrm{ft}$., January, BurltDavy 1193; Eastriood in Colonial Herb. 1286; Woodbush, $4900 \mathrm{ft}$. October, O'Connor in Herb. Forest Dept. 2198; J.ane-Poole in Herb. Forest Dept. 547; Grenfell in Colonial Herb. 1112 ; without collector in Herb. Forest Dept. 542.

Known as the Cape Plane, Rooihout, Machailo, Rooi Yzerhout, Morelle.

0. Holstii (Engl. in Engl. Pflanzenw. Ostafr. c. 273).

A tree of timber size. Bark rough. Branchlets varying in colour from light to dark brown, scarcely pustulate, not flaking. I.eares deciduous, $5-8 \mathrm{~cm}$. long, $0 \cdot 8-2 \mathrm{~cm}$. broad, lanceolate, acuminate, obtuse at the apex, narrowed at the base into a short petiole, midrib distinct above and beneath, lateral veins not evident, with the margins serrated and with the serrations very erect, glabrous. Inflorescence on short shoots in abbreviated racemes, up to 7 -flowered. Pedicels $1 \cdot 3-2 \cdot 7 \mathrm{~cm}$. long, terete, articulated 1--3 mm. from the base. Sepals $1 \mathrm{~cm}$. long, lengthening in the fruit, $0.5 \mathrm{~cm}$. broad, elliptic, rounded at the apex, glabrous (in dried specimens the folding of the sepals gives them the appearance of being acuminate). Petals $8 \mathrm{~mm}$. long, $5 \mathrm{~mm}$. broad, obovate, rounded at the apex, narrowed at the base into a short broad claw. Filaments $5 \mathrm{~mm}$. long; anthers $2 \mathrm{~mm}$. long, oblong in outline, dehiscing by apical slits. Ovary of 4-5 carpels about $1 \mathrm{~mm}$. long; style $6 \mathrm{~mm}$. long; stigma globose, faintly lobed. Fruit ellipsoid, attached to the torus at one end.

Eastern Region.-Tembuland, Engcobo Mtn., Flanagan 2696. Natal: Ngomi, Tustin in Herb. Forest Dept. 3115; Ingeli Forest Reserve, December-January, Chilvers in Herb. Forest Dept. 1944, 1946 ; Tustin in Herb. Forest Dept. 2907, 2984.

Transvaal.-Pietersburg Div.: Woodbush, December, Botha in Herb. Forest Dept. 2935 ; $49 \mathrm{co}$ ft., November, O'Connor in Herb. Forest Dept. 2197; without collector in National Herb. 1242. Lydenburg Div.: Pilgrims Rest, Van der Merwes Bush, 5400-5750 ft., January, Burtt-Davy 1408; Drakensberg at Pilgrims Rest, Collector (?) in Herb. Forest Dept. 549. Barberton Div.: Barberton, Rogers 14996.

This tree flowers in November and sets its fruits in January, The sawyers call it the "real red pear" as distinct from Scolopia. In the Woodhush it is known as "rooi yzerhout."

0. natalitia (Engl. et Gilg. in Engl. "Bot. Jahrb.," 33, 236 ; name onlyi.

Large shrub or small tree. Branches usually with prominent lenticels, often numerous, but not appearing lejidote to the naked eve. I.eares subsessile, $2-9 \mathrm{~cm}$. long, $0 \cdot 5-2 \cdot 5 \mathrm{~cm}$. broad, usually lanceclate, more rarely lanceolate-elliptic or lanceolate-linear, cuneate or slightly narrowed at the base, very rarelv rounded at the base, obtuse or rounded at the apex, with serrated, very rarely entire margins, with the teeth usually incurved; the mid-rib distinct above and beneath and the lateral vein evident. Inflorescence either solitary or 2-nate from the apex of short shoots, or 2-5-nate arising in the axils of the leaves, very rarely in abbreviated racemes. Pedicels $0 \cdot 4-1.5 \mathrm{~cm}$. long, articulated at the base or 
$1 \mathrm{~mm}$. from the base. Sepals $7-8 \mathrm{~mm}$. long, $4.5-5.5 \mathrm{~mm}$. broad, elliptic or rounded at the apex. Petals 0.9-1.2 $\mathrm{cm}$. long, 6-7 mm. broad, obovate, narrowed at the base. Filaments $1.5-2 \mathrm{~mm}$. long; anthers 1.5-2.5 mm. long, oblong in outline. Ovary of 5-9 carpels : style $4.5-6.5 \mathrm{~mm}$. long; stigma either discoid or stigmas as manv as the carpels. Fruit $0.8-1.4$ $\mathrm{cm}$. long, 5-9 mm. in diameter, ellipsoid, more rarely subglobose.--O. atropurpurea, var. natalitia, "Flora Capensis," I, 448; Sim, "Forest and Forest Flora," p. 163.

Coast Region.--Uitenhage Div.: Uitenhage, May, E. and Z. 935 ; Motinsele Forest, December, Fegen in Herb. Forest Dept. 1816, 1818.

Eastern Region.- Natal: Berea, 200 ft., August, Wood 10060 ; Wood in Natal Govt. Herb. 10062, 10064 ; without precise locality, Wood 6418; near Durban, Wood 72 ; Benvie, Karkloof, 4000-500 ft. Wylie in Natal Goit. Her7. 10826 ; (Wood 10034) ; Umzinyati, 200-500 ft., October, Wood 11458; without precise locality, Cooper 1252. 2587 .

Orange Free State: Elandshoek. September, Rogers in Herb. Transvaal Museum

Swaziland.-Komassan Valley, Havelock Concession, July, Galpin 983.

Transvaal.- Without precise locality, Miss Stent, in Herb. Transvaal Mus. 8779. Pietersburg Div.: The Downs, Rogers 22133; Tzaneen, Rogers 12540. Barberton Div.: Umvoti Creek, near Barberton, $3000 \mathrm{ft}$., November, Galpin 660; Rogers 20267; Nelspruit, October, Breyer in Herb. Transwaal Mus. 17701; between White River and Nelspruit, Burtt-Davy 1510; Carolina, September, Roberts in Herb. Transvaal Mus. 15874.

\section{O. leptoclada (()liv., "Fl. Trop. Afr." I, 318).}

A bush, 2-3 ft. high (Galpin). Branches somewhat pustulate with ash-grey bark and with the epidermis peeling off in membranous flakes. Young leaves $2 \cdot 5-6.5 \mathrm{~cm}$. long, $0 \cdot 6-1$ $\mathrm{cm}$. broad, lanceolate, subacute, tapering at the base, with serrated margins, sometimes subentire. Mature leares 5-11.5 cm. long, 1.4-3.4 cm. broad, mostly oblanceolate, sometimes lanceolate-elliptic, rounded at the apex, usually long-attenuate at the base, more rarely only narrowed, with the mid-rib prominent above and beneath, and the lateral veins distinct, with serrated margins, rarely subentire. Infiorescence mostly unbellate on abbreviated shoots, 3-4-flowered, sometimes flowers solitary. Pedicels $1-2.5 \mathrm{~cm}$. long, articulated at the very base. Sepals $7 \mathrm{~mm}$. long, $5 \mathrm{~mm}$. broad, ohovate or elliptic, rounded at the apex. Petals $1 \mathrm{~cm}$. long. $5 \mathrm{~cm}$. hroad, obovate, rounded at the apex, narrowed into a claw at the base. Filaments $3.5 \mathrm{~mm}$. long ; anthers $1.5 \mathrm{~mm}$. long, oblong-linear. Ovary of 5 carpels; style $4.5 \mathrm{~mm}$. long; stigma capitate. Fruit about $6 \mathrm{~mm}$. in diameter, subglobose.

Transvaal.-- Barberton Div.: Barberton, November, Rogers 18264, and in Herb. Transiaal Mus. 15976; mountain sides, Moodies, near Barberton, September-October, $3500 \mathrm{ft}$. Galpin 590 ; mountains near Barberton, Bolus 7693. Lydenburg Div. : Pilgrims Rest, c. 3500 ft., October, Rogers, 23068, and in Herb. Transvaal Mus. 20541.

Rhodesia,-North-West Rhodesia: Pemba, 3500 ft., October, Rogers 8579; Ndola, October, Allen, 304 ; Chilanga, 3500 ft. Rogers 8455. Umtali Div. : Odanzi River Valley, Teague 399, 497.

\section{Belgian Congo: Elisabethville, 4800 ft., Rogers 10194.}

\section{0. atropurpurea [1 C. in "Ann. Mus. Par.," XVII (1811), 412].}

Small shrub, 3-5 ft. high. Branches densely covered with prominent lenticels giving them a lepidote appearance to the naked eve. Leares subsessile, $0 \cdot 8-5 \mathrm{~cm}$. long, $0 \cdot 4-1 \cdot 9$ cm. broad, usually elliptic, rarely elliptic-ovate, elliptic-oblong, or elliptic-lanceolate, more rarely lanceolate, obtuse, rounded or slightly narrowed at the base, with serrated margins and the teeth usually triangular erect and acute, more rarely incurved, with the mid-rib 
prominent above, and lateral veins evident. Flowers solitary at the apex of short shoots, very rarely 2 -nate. Pedicels $1-1.5 \mathrm{~cm}$. long, articulated at the base or about $1 \mathrm{~mm}$. from the base. Sepals 6-7 mm. long, 3-6 mm. broad, elliptic, elliptic-ovate or elliptic-oblong, rounded at the apex. Petals $0.9-1 \cdot 3 \mathrm{~cm}$. long, obovate, cuneate at the base. Filaments 2-2.75 mm. long; anthers 2-3.5 mm. long, oblong or linear ir outline. Ovary of 5-6 carpels ; style 5-7 mm. long; stigmas as many as the carpels. Fruit $7 \mathrm{~mm}$. long, about $5 \mathrm{~mm}$. in diameter, subglobose.-"Flora Capensis," I, 448; Sim, "Forests and Forest Flora," p. 163, pl. xxix, fig. 2.

Cape Province.-- Caledon Div. : Genadendal, $2500 \mathrm{ft}$., April, Schlechter 7749; Bedford, June, Miss Nicol 49. Knysna Div. : Woods at Knysna, Newdigate in Herb. Albany Museum; Watton in National Herb. 1419. Port Elizabeth Div.: Van Stadens, September, Mrs. Patterson 737, MacOuan in Cape Govt. Herb. Albany Div.: Howisons Poort, near Grahamstown, MacOwan in Herb. Austro-Afric. 1766 ; Rockliffe, near Sidbury, November, Miss Daly 771 ; Grahamstown Commonage, $2000 \mathrm{ft}$., September, Schönland 570 ; rocky hills near Grahan:stown, 2000-2500 ft., Angust, Galpin 48 ; near Grahamstown, September, MacOwan 111; and in Natal Govt. Herb. 850; January, Rreyer in Herb. Transvaal Mus. 16866 ; Signal Hill, near Grahamstown, 2200 ft., September, Bolus 1920. Queenstown Div. : Among rocks on hillside, Junction Farm, Queenstown, 2500 ft., Miss Wiggill in Herb. Galpin 8257. East London Div.: East London, December, Breyer in Herb. Transvaal Mus. 16544. Komgha Div.: Wood near Prospect Farm, November, Flanagan 322. Stockenstrom Div.: In bush at Willisdale, September, Scully 77 ; Kat River, Bcrtels ; Katherg Forest, January, Stapels in Herb. Forest Dept. 2937, 2938 Stutterheim Div. : Stutterheim, December, Rogers 12726; Transkei, Umtata, Convent School Herb. 194; Kentani, 1200 ft., October, Miss Pegler 194; rocky spots near Bazya, 2000 ft., October, Baur 258 ; Maseko Forest, Negeleni, December, Fegen in Herb. Forest Dept. 1819 ; Pondoland, Mgazama River, near McAllister's Drift, Port St. Johns, Miller in Herb. Forest Dept. 3024 .

Natal.-Near Umkomaas River, October, Tyson 2659 ; Natal Bay, Gueinzius ; without locality, Wood 190.

Zululand.-Oudeni Forest, 6000 ft., January, Davis 108.

Transvaal.-Barberton Div.: Near Barberton, September, Bolus. A small stunted shrub. Plentiful on edge of forest, but does not appear to seed freely (Fegen). leaves.

Var. angustifolia, Phillips. Differs from the type in having smaller, narrower lanceolate

Transvaal.-Barberton Div.: Margin of wood, upper Moodies, $4500 \mathrm{ft}$., June, Galpin 963, and in Natal Government Herb. 8761. Ermelo Div.: Nooitgedacht, December, Mrs. Pott 5096, and in Herb. Transvaal Mus. 14933. Lydenburg Div.: Between Pilgrims Rest and Sabi, Rogers 23410. (Galpin).

Swaziland.-Havelock Concession, Saltmarsh in Herb. Galpin. A shrub $3 \mathrm{ft}$. high

0. pretoriensis, Phillips ("Flowering Plant S. Afr.," vol. ii).

Branchlets with light to dark-brown bark, peeling in membranous strips, not distinctly pustulate. Leaves $1.5-3.8 \mathrm{~cm}$. long, $0 \cdot 5-1 \cdot 7 \mathrm{~cm}$. broad, lanceolate, obovate, elliptic, or oblanceolate (mostly ohlanceslate), ohtuse at the apex, cuneate, more rarely rounded at the base, with serrated margins and with the mid-rib distinct and lateral veins evident. Flowers solitary, very rarely 2 -nate, arising at the apex of abbreviated shoots. Pedicels $1-1.5 \mathrm{~cm}$. long, articulater at the base or 1-2 $\mathrm{mm}$. above the base. Sepals 7-8 mm. long, 4-5 mm. broad, ovate or elliptic, rounded at the apex, sometimes 2-3-lobed at the apex, enlarging in fruit. Petals $1.5 \mathrm{~cm}$. long, $8.5 \mathrm{~mm}$. broad, obovate, rounded at the apex, narrowed at 
the base into a claw. Filaments $4.5 \mathrm{~mm}$. long; anthers $2 \mathrm{~mm}$. long, oblong in outline. Ovary of 4-5 carpels; style $5 \mathrm{~mm}$. long; stigmas as many as the carpels. Fruit 7-8 mm. long, 5-6 mm. broad, more o less ellipsoid.

Transvaal.- Pretoria Div. : Below River Redoubt, Daspoort Rand, October (fruits), Pole Evans 157; Pretoria, December (fruits), Nelson in Herb. Transvaal Mus. 11709; February (fruits), Miss Leendertz 65, and in Herb. Transvacl Mus. 4199 ; November (flowers) Miss Leendertz 301 ; Meintjes Kop, March (fruits), Pole Evans 353; Kopje near Gezina, Phillips in National Herb. 1422; Fouche in National Herb, 1491; Moorddrift, October (fruits), Leendertz 2131, and in Herb. Transvaal Mus. 7333 ; Rikatla, October (fruits), Junod 147, and in Herb. Transvaal Mus. 20146; near Messina, c. $1800 \mathrm{ft}$. , November (fruits), O'Connor in Herb. Forest Dept. 1936; Messina, October (fruits), Rogers 19398, 20029, 19244, and in Herb. Transvaal Mus. 17762. 


\section{$2 \mathrm{BHL}$ Biodiversity Heritage Library}

Phillips, E P. 1922. "The Genus Ochna ." Bothalia 1, 87-96.

https://doi.org/10.4102/abc.v1i2.1777.

View This Item Online: https://www.biodiversitylibrary.org/item/133653

DOI: https://doi.org/10.4102/abc.v1i2.1777

Permalink: https://www.biodiversitylibrary.org/partpdf/168123

\section{Holding Institution}

Smithsonian Libraries

\section{Sponsored by}

Biodiversity Heritage Library

\section{Copyright \& Reuse}

Copyright Status: Not in copyright. The BHL knows of no copyright restrictions on this item.

This document was created from content at the Biodiversity Heritage Library, the world's largest open access digital library for biodiversity literature and archives. Visit BHL at https://www.biodiversitylibrary.org. 